\title{
KINESISK YOGA?
}

\author{
SINIFICERING AF YOGA-BEGREBET I SINOLOGISKE,
}

TERAPEUTISKE OG NYRELIGIØSE SAMMENHÆNGE

\author{
Tao Thykier Makeeff 10 \\ Postdoc, Universitetet i Stavanger \\ tao.makeeff@uis.no
}

\begin{abstract}
This article provides a conceptual history (Begriffsgeschichte) of the use of the word yoga in the context of both scientific, therapeutic, and religious approaches to Chinese cultural history, with a focus on somatic practices commonly associated with Daoist traditions. Under the heading Chinese yoga, the author investigates how historical practices such as neidan, daoyin, kaimen, zhanzhuang, gusha, fangzhongshu as well as new therapeutic innovations are referred to as types of yoga such as Taoist yoga, meridian yoga, yin yoga, and sexual yoga. The article traces the origins of variations of the concept of Chinese yoga to the 1920s and 1930s in publications by Richard Wilhelm and C. G. Jung, Cary F. Baynes, and Arthur Waley, follows its reception in the hippie milieu of the 1960s and 1970s, and demonstrates how references to various forms of Chinese yoga have been, and are still being used in both academic research, and therapeutic and new religious milieus.
\end{abstract}

$$
\begin{gathered}
\text { KEYWORDS } \\
\text { Begriffsgeschichte }- \text { Chinese religion }- \text { conceptual history - Daoism - Jung - } \\
\text { neidan - sinology - yoga }
\end{gathered}
$$

\section{INDLEDNING}

Denne artikel handler ikke om hvad yoga er, hvad yoga gør, hvor yoga kommer fra, eller hvor yoga er på vej hen, men om selve ordet yoga i et transnationalt begrebshistorisk perspektiv. Mit fokus er, at undersøge hvordan og hvorfor ordet yoga er blevet brugt til at beskrive legemsøvelser der helt, eller delvist har deres oprindelse i kinesisk historie. Hvilke fænomener mennesker italesætter som yoga fortæller os både noget om deres opfattelse af selve ordet og af de fænomener de vælger at beskrive med det. Når et moderne 
fitnesscenter i København, Lund, Stockholm eller Oslo udbyder træning i yin yoga, eller en alternativ behandler omtaler yoga som en træningsform der balancerer meridianerne er dette ikke kun udtryk for en moderne romantiserende samtænkning af fjernøstlige fænomener i en mere eller mindre uklart defineret idé om Orienten - selvom dette ofte også er en del af forklaringen. Der er mange eksempler på brugen af ordet yoga i sammenhæng med receptionen af kinesiske legemøvelser udenfor Kina; Taoist yoga, meridian yoga, yin yoga og sexual yoga er nogle af dem. ${ }^{1}$ Jeg har af praktiske hensyn valgt, at bruge begrebet kinesisk yoga som en fællesbetegnelse for alle disse. ${ }^{2}$ Som jeg vil vise, går brugen af ordet yoga i disse sammenhænge tilbage til nogle af den moderne sinologis tidlige moderne pionerer, såvel som til personer der var centrale inspirationskilder for senere terapeutiske og nyreligiøse miljøer, og ideen om kinesisk yoga er del af en historie hvor grænserne mellem forskere, oversættere, forlæggere og aktører i nyreligiøse og alternative terapeutiske miljøer kan være flydende.

\section{Yoga MELLEM INDOLOGI OG SiNOLOGI}

Indenfor indologien og sinologien har der længe været faglig diskussion om i hvilken grad legemsøvelser fra indisk og kinesisk historie har påvirket hinanden. Denne diskussion er for forståelsen af ældre historie og som led i forståelsen af brugen af ordet yoga i både sinologien og indenfor det nyreligiøse og aternative terapeutiske miljø, til at beskrive særlige typer legemsøvelser. I det følgende vil jeg give en kronologisk gennemgang af hovedpunkter i diskussionen af den gensidige påvirkning mellem indisk og kinesisk kropshistorie indenfor indologien og sinologien med fokus på yoga-begrebet.

Den franske læge og indolog Jean Filliozats artikel «Taoïsme et Yoga» (1969) i tidsskriftet Journal Asiatique må betragtes som et af de tidlige eksempler på det indologiske studie af forholdet mellem yoga og kinesisk religiøs kultur og legemsøvelser. ${ }^{3}$ Filliozats

1. Jeg fokuserer i denne artikel primært på engelsksprogede tekster (samt udvalgte franske og tyske sinologiske hovedværker). Dog er det min vurdering, på grundlag af supplerende oversigtsstudier af et stort udvalg af tilsvarende kilder på fransk, spansk, tysk og de skandinaviske sprog, at mine pointer om de engelsksprogede kilder også afspejler begrebsbrugen i kilderne på disse andre sprog.

2. Jeg har af pladshensyn valgt at fokusere primært på eksempler på brugen af ordet yoga i sammenhæng med referencer til daoistiske praktikker og klassisk og traditionel kinesisk medicin. Min analyse af begrebet i akademiske sammenhænge i sinologien er også overvejende fokuseret på daoismestudier. En tilsvarende begrebshistorisk undersøgelse af brugen af ordet yoga i buddhistiske sammenhænge i kinesisk historie og indenfor sino-buddhistiske studier ville være både mulig, relevant og interessant.

3. Filliozat udgav i 1949 en artikel med samme titel i Dân Viet Nam, No 8, Hanoi, 1949. Denne omtales således: «conférence publée» (Sino-Indian Studies; [Journal] - Volume 5, Issues 3-4 - Page 215). Det er uklart om indholdet i artiklerne er det samme. Den er sandsynligvis baseret på et foredrag med samme titel han holdt 16 maj 1949 på Louis Finot Museet i Hanoi. Artiklen fra 1969 er den der almindeligvis refereres i blandt andet bibliografiske oversigter, men Needham og Eliade henviser i deres arbejde til versionen fra 1949 og Alter (2005) angiver den som udgivet i [1949] (1964). 
artikel var tilsyneladende inspireret af en tidligere udgivelse af Henri Maspero i samme tidsskrift næsten to årtier tidligere, men hans større fokus på spørgsmålet om indisk ophav var en tilføjelse til Masperos arbejde. Filliozats artikel er interessant, men opererer desværre ikke med en præcis definition på hvilke daoistiske øvelser den indiske påvirkning skulle have berørt. Hans hovedfokus er på hvilken indisk påvirkning der generelt har været på daoisme og ikke kun på specifikke navngivne legemsøvelser. Han fremdrager dog adskillige eksempler på øvelser, blandt andet en daoistisk metode han kalder «souffle de soleil» (sol-åndedræt) ${ }^{4}$ som værende upåvirket af, og væsensforskellig fra den indiske øvelse suryabheda, som han refererer til som «mise à part du soleil»» (at opspare eller akkumulere sol, Filliozat 1969: 60-61). ${ }^{5}$ Ligeledes nævner han, at de daoistiske metoder, der involverer, at skære tænder og sluge ens eget spyt ikke synes, at have inspiration fra Indien, for: «chez les Indiens, le salive est un horreur» (hos inderne er spyt en rædsel, Filliozat 1969: 59). ${ }^{6}$ Filliozat fremhæver dog for eksempel åndedrætsøvelser som et områder der synes, at være blevet påvirket af indisk kropskultur.

I 1983 helligede Joseph Needham under overskriften «Physiological Alchemy» en del af den femte bog af sit enorme opslagsværk Science and Civilisation in China til forholdet mellem yoga, alkymi og daoisme. Needham beskæftiger sig her ikke kun med kropsøvelser og neidan (indre alkymi) men med farmakologiske aspekter af waidantraditionen (ydre alkymi). I spørgsmålet om legemsøvelser er han enig med Filliozat $\mathrm{i}$, at der er ligheder mellem historiske kinesiske og indiske åndedrætsøvelser. Needham fremhæver også ideen om meridiansystemer og akupunkturpunkter som et lighedspunkt, men mener dog, at disse fandtes i Kina inden nogen indisk påvirkning, da de omtales i Huangdi Neijing (Den Gule Kejsers Klassiker) (Needham 1983: 265). Needham medgiver også, at referencer til metoder til at frembringe og sluge eget spyt er langt mere udbredte i det oldkinesiske materiale end det indiske. Dog fremhæver han, at disse ikke er helt fraværende, som Filliozat mente, men findes i tantrisk hathayoga som kechari mudra (Needham 1983: 265). I store træk er Needhams opfattelse, at omend der findes lighedspunkter mellem kropsteknikker og mange eksempler på kontakt og udveksling mellem oldtidens Kina og Indien, så er spørgsmålet om diffusion vanskeligt og, at store dele af de daoistiske øvelser må betragtes som autoktont kinesiske.

Sinologen Livia Kohn, der er ekspert i daoistisk kropshistorie og iøvrigt selv praktiserer og underviser i kinesiske legemsøvelser og meditation, skriver i en artikel om yoga og daoyin fra 2007, at det på trods af historisk påvirkning, terminologisk sammenfald og nogen grad af koreografisk lighed, ikke er rimeligt, at tale om yoga og daoyin som beslægtede systemer, da de på fundamentale punkter griber kroppen an forskelligt:

\footnotetext{
4. Min oversættelse

5. Min oversættelse

6. Min oversættelse
} 
Given the enormous differences from other forms of Asian body cultivation in historical origins, fundamental worldview, and applied techniques, it is safe to conclude that daoyin is indeed quite unique in its concepts and practices. This is so despite the fact that it matches Yoga in certain basic similarities in body postures and energy circulation; that there was already rich cultural contact between Persia, India, and China in the first millennium BCE; that evidence shows the use of various technical Sanskrit terms in Chinese; and that Buddhist masters undoubtedly brought physical and breathing practices to China, in addition to scriptures and meditations, in the first few centuries CE. In spite of all this, examining the deeper levels of the two systems, it becomes clear that Yoga and daoyin are completely at odds in the way they deal with the body (Kohn 2007: 127, kursiv i original).

I en artikel fra 2009 går indologen Joseph S. Alter i rette med Kohn, såvel som med Needham, hvis arbejde på området han mener er sinocentrisk. Ifølge Alter er ligheden mellem pranayama og qigong eller - som han specificerer det — daoyin fra Tang-dynastiet slående selv for en «casual observer.» Alter antyder indledningsvis at det er nærliggende, at betragte de to som kulturelt og historisk varierede former af det samme fænomen: «One could surmise that they are, in fact, the same thing expressed somewhat differently on account of distinct circular historical orbits and variegated patterns of cultural contextualization» (Alter 2009: 125). Dog nuancerer han dette senere i teksten, hvor han nævner, at en binær fremstilling af problematikken ikke er fyldestgørende og, at lighedspunkter eller forskelle er produktet af selektive fremstillinger: «Yoga and Taoism can be made to look much more alike than they are made to look by way of Needham's binary reasoning». Alter fremhæver med reference til indologen Kenneth Zysk (1993) og sinologen Nathan Sivin (1978), at asana forstået som bevægelser og positurer, ikke kan spores til Indiens oldtid (hvor det kun betød sæde) hvorimod prana-begrebet har en længere historie som operationelt filosofisk begreb i sanskritlitteratur. Baseret på dette, fremhæver han den høje grad af kompleksitet i studiet af transnational, historisk diffusion af legemskultur og foreslår, at man fremfor at fokusere på isolerede bevægelsestyper og koreografiske ligheder, må forsøge at sammenligne og analysere mere paradigmatiske konstellationer:

What this does is complicate the historical dynamics of knowledge exchange between «India» and "China», since it is not simply a matter of looking for the antecedents of asana in daoyin, or vice versa. Rather, one must look into the way in which a whole spectrum of things - breathing, exercising, diet, sexuality, and meditation - are implicated in practices oriented toward the goal of embodied immortality. In other words it is relatively insignificant if the specific techniques of breathing or manipulating the body are different - since there is considerable difference within each «tradition»-if the primary goal is, in essence, the same (Alter 2009: 227, kursiv i original). 
Alter argumenterer for, at den høje grad af kontakt mellem Syd- og Østasien gjorde Centralasien til et «center of cosmopolitan philosophy» og foreslår, at der på trods af definitive beviser sandsynligvis forekom kulturelle lån også når det gælder yoga og daoisme. Han understreger dog, at videre forskning skal udføres velovervejet og nøje eftersom: «it is much too easy to look at a practitioner of hatha yoga and a practitioner of qigong and jump to the erroneous conclusion that both reflect ancient history and that they are simply the same» (Alter 2009: 228). I stedet for at argumentere for identifikation mellem de to traditioner foreslår Alter, at der er tale om sammenlignelige udviklinger: «In fact hatha yoga and qigong reflect comparable developments in what might be called the literalization of philosophy and the gross embodiment of inner alchemy since the thirteenth century» (Alter 2009: 228).

Jeg er ikke selv sinolog eller indolog og efter en gennemgang af hovedtrækkene i den akademiske diskussion af disse spørgsmål, må jeg nøjes med at konkludere, at der stadig er stor uenighed på området. Til dels skyldes dette, at de involverede forskere ikke konsekvent diskuterer de samme fænomener eller den samme empiri, eller stiller fælles undersøgelsesspørgsmål. Diskussionen er derfor vanskelig, at danne sig et sammenhængende overblik over. Det er påfaldende i den akademiske diskussion af dette emne, at flere indologer betoner en påvirkning fra Indien mod Kina, mens fremtrædende sinologer afviser dette, hvorfor man kunne mistænke, at der er nogen grad af akademisk gatekeeping på spil. En anden tydelig udfordring ved diskussionen af forholdet mellem yoga og kinesisk religiøs og terapeutisk kropskultur er naturligvis at yoga-begrebet er polyvalent og har haft skiftende betydninger historisk. Det er uklart hvornår der er tale om hathayoga eller andre former for yoga som den yoga der skulle have påvirket kinesiske legemøvelser. Ydermere kompliceres dette noget af, at moderne hathayoga som blandt andet Alter (2004), De Michelis (2004), Singleton (2010) og Strauss (2005) har påpeget, må forstås som et internationalt fænomen der har gennemgået betydelige forandringer i historiens løb — som det i øvrigt også er tilfældet med kinesiske legemsøvelser. Den akademiske diskussion om påvirkning mellem indiske og kinesiske kropstraditioner foregår stadig, hvilket illustreres ved flere nylige workshops og konferencebidrag, ofte i form af dialog mellem eksperter i kinesisk og indisk kropshistorie. I 2019 afsluttedes en længere workshop i yoga-studier afholdt af SOAS Centre of Yoga Studies med en faglig paneldiskussion mellem Louis Komjathy (University of San Diego) og James Mallinson (SOAS) under titlen Alchemy in Daoism and Hatha Yoga og året inden, i 2018 arrangerede Dan Lusthaus (Harvard University) ved AAR-konferencen sessionen Yoga in India and Chi-

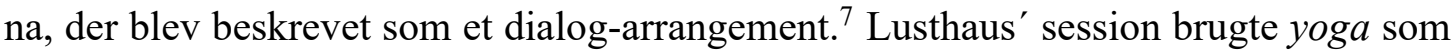

7. En af deltagerne ved sessionen, sinologen Dominic Steavu-Balint (University of California, Santa Barbara), præsenterede ved denne session paperet «Brahmano-Daoist European Yoga? Tracing the Peculiarly Global History of a Medieval Chinese Bodily Discipline». Dette bidrag er desværre ikke udgivet efterfølgende. 
et komparativt begreb, der ifølge arrangørerne dækkede over et udvalg af kropslige teknikker fra indisk og kinesisk historie: "The term 'yoga' is intended in a broad sense, to include bodily disciplines, hygienic regimens, inner alchemy, breathing techniques, body maps, pursuit of physical immortality, etc» (Muller 2018).

Som de ovenstående eksempler demonstrerer er der altså på den ene side en pågående akademisk diskusion af yoga som et indisk fænomen og dets forhold til mere eller mindre klart definerede kinesiske legemøvelser. På den anden side bruges ordet yoga også som et komparativt begreb, til at beskrive kinesiske legemsøvelser, der ellers har kinesiske navne allerede. For at forstå baggrunden for dette og for, at give læseren baggrundsviden til min efterfølgende gennemgang, af nyreligiøs og terapeutisk litteratur, vil jeg i det følgende afsnit kort opridse hvordan ordet yoga er blevet brugt i sinologien og hvordan de tidlige sinologiske eksempler på denne brug opstod under direkte påvirkning af nøglepersoner i 1920ernes og 1930ernes terapeutiske miljø.

\section{KINESISK Yoga I SinOLOGIEN OG JungS PÅVIRKNING}

Udover den til tider uklare brug af yoga-begrebet i den akademiske diskussion af historisk påvirkning mellem Kina og Indien øges forvirringen yderligere af, at flere religionshistoriske underdiscipliner af sinologien har brugt yoga og relaterede ord, som faglige begreber i studiet af kinesisk kropshistorie. De tidligste eksempler på ideen om kinesisk yoga eller mere specifikt daoistisk yoga finder vi i slutningen af 1920erne i Richard Wihelm og C. G. Jungs kommenterede oversættelse af den daoistiske tekst Taiyi Jinhua Zongzhi. Ydermere forstærkedes dette nogle år senere gennem sinologen Arthur Waleys kommenterede oversættelse af et af de daoistiske hovedværker, Daodejing. Udbredelsen og udviklingen af variationer over begrebet kinesisk yoga, synes altså at være foregået parallelt i - såvel som med udveksling mellem terapeutiske - nyreligiøse og akademiske miljøer. Særligt to nært beslægtede grene af sinologisk religionforskning, daoismestudier og neidan-studier er her interessante. Neidan-studier er i store træk en underkategori af daoismestudier og begge må, sådan som de udøves indenfor sinologien, klasificeres som filologisk baserede religionshistoriske specialområder. Som det ofte er tilfældet i filologisk religionshistorie, har flere af de centrale forskere haft en dobbeltrolle som både oversættere og religionshistorikere og ofte er disse to roller flettet sammen, eftersom der i mange tilfælde er tale om at forskerne oversætter nye kildetekster og analyserer dem religionshistorisk. Der er også eksempler på forskere der har deltaget aktivt i religiøse miljøer og gennem initiation har fået adgang til kildemateriale, som de efterfølgende har oversat eller anvendt på anden måde i deres akademiske virke. I sinologien er Kristofer Schipper, der er initieret i den daoistiske Zhengyi-sekt (i Taiwan) og Louis Komjathy, der er initieret i Quanzhen-sekten (Huashan-linjen), klassiske eksempler på dette. Men for at finde den tidligste brug af ordet yoga som begreb i sinologien må vi tilbage til de første årtier af det 20. århundrede, til nogle af de tidlige moderne pionerer i oversættel- 
sen og populariseringen af kinesiske religiøse kildetekster, Richard Wilhelm, C. G. Jung og Arthur Waley.

Den tyske sinolog, teolog og Kinamissionær Richard Wilhelm (1873-1930) samarbejdede med Carl Gustav Jung (1875-1961) på flere udgivelser af kinesiske religiøse kildetekster. Den mest kendte af disse er nok Yijing, som Wilhelm oversatte og udgav med en kommentar af Jung i 1924, men det var i deres andet store samarbejde Das Geheimnis Der Goldenen Blüte (oversat til dansk i 1993 af Hugo Hørlych Karlsen under titlen Den Gyldne Blomsts Hemmelighed: Den Klassiske Kinesiske Livets Bog), at ideen om kinesisk yoga tilsyneladende blev introduceret. Dette var en oversættelse af den daoistiske neidan-tekst Taiyi Jinhua Zongzhi der populært tilskrives Lü Dongbin fra det sene Tang-dynasti. Wilhelms tyske oversættelse af teksten var det første eksempel på en kinesisk alkymistisk tekst i tysk udgivelse. Den udkom første gang i 1929 og kort tid efter på engelsk i 1931 oversat (fra Wilhelms tyske udgave) af den nordamerikanske jungianske psykolog Cary F. Baynes (1883-1977). Bogen udkom kort tid inden Wilhelms død i marts 1930, men i sin selvbiografi omtaler Jung at Wilhelm havde sendt ham manuskriptet allerede i 1927 (Jung [1961] 1989: 197). Wilhelm bruger ordet yoga flere steder i den originale tyske tekst, både i sit forord og i selve kildeteksten. I kildeteksten bruges det i en enkelt sætning (Wilhelm og Jung [1929] 1986: 108), hvor tekstens kinesiske forfatter forklarer hvordan dennes tilgang adskiller sig fra det Wilhelm kalder den «buddhistiske yogaretning» (buddhistische Yoga-Richtung). Jung bruger sin kommentar til Wilhelms tyske oversættelse yoga-begrebet til at tale om det han kalder «kinesiske yogaøvelser» (chinesische Yogaübung), men også til at beskrive indisk kundaliniyoga. Endvidere omtaler Jung i senere udgaver (Wilhelm og Jung [1929] 1986: 180) af den tyske udgivelse, i et mindeord til Wilhelm hvordan denne i løbet af sin tid i Kina modtog belæringer af en daoisten Lao Naixuan (Wilhelm og Jung omtaler ham som Lau Nai Süan) vedrørende «Yijings psykologi» (die Psychologie des I Ging) og «kinesisk yogafilosofi» (chinesische Yoga-Philosophie). I alt optræder ordet yoga 12 gange i Wilhelm og Jungs tyske udgave af Das Geheimnis Der Goldenen Blüte, men udover de to nævnte eksempler hvor begrebet bruges til, at tale om specifikt daoistiske fænomener og et enkelt eksempel omhandlende buddhisme, optræder ordet enten i referencer til indisk kultur eller til bibliografiske henvisninger. Det er her interessant at bemærke, at ordet yoga til sammenligning optræder 19 gange i Baynes' engelske oversættelse og endnu mere interessant er det, at 10 af disse tilfælde er i sætninger der handler om kinesiske kropsteknikker. Selvom det lader til, at det oprindelig var Wilhelm og Jung der først introducerede ideen om kinesisk yoga, spillede Baynes altså tilsyneladende en betydelig rolle $\mathrm{i}$, at forstærke dette begreb, ved at bruge det i større udstrækning i sin engelske oversættelse end Wilhelm og Jung gjorde i deres tyske tekst.

I de samme år finder vi ideen om kinesisk yoga i en udgivelse af sinologen Arthur Waley (1889-1966), der var en respekteret oversætter af klassisk kinesisk, men ulig Wilhelm, ikke talte moderne mandarin og aldrig selv besøgte Kina (Honey 2001:225). «That 
the Chinese Quietists practised some form of self-hypnosis no one familiar both with the yoga literature of India (whether Hindu or Buddhist) and with Taoism would, I think, be likely to dispute» (Waley [1934] 1977: 116). Således skrev Waley i 1934 i et af de seks appendikser i The Way and Its Power: A Study of the Tao Tê Ching and Its Place in Chinese Thought, hans kommenterede oversættelse af Daodejing. Det er bemærkelsesværdigt, at han valgte at kalde dette appendiks «Taoist Yoga». Waley bruger, som citatet ovenfor understreger, adskillige begreber hentet fra andre kulturelle og religiøse sammenhænge til at oversætte kinesiske ord. I samme udgivelse omtaler Waley «yoga, with complete suspension of the outward senses» som noget der med sikkerhed blev praktiseret af indviede daoister (Waley [1934] 1977: 57) hvilket synes, at korrespondere med hans brug af begrebet quietism som beskrivelse af daoistiske praktikker. Med henvisning til Huainanzi (kapitel 7) ${ }^{8}$ foreslår Waley, at et af de daoistiske hovedværker Zhuangzi «deals with the technique of Taoist yoga» (Waley [1934] 1977: 154), ligesom han mener at buddhistisk terminologi er "partly derived from that of Taoist yoga» (Waley [1934] 1977: 119). Her er det interessant at bemærke, at Waley afviger fra Wilhelm i enten sit syn på Zhuangzi, sin brug af ordet yoga, eller begge dele. Wilhelm mente at Zhuangzi «scorned all the hocus-pocus of yoga practice», selvom han ifølge Wilhelm praktiserede meditation og baserede sit intellektuelle system på erfaringer fra dette (Wilhelm og Jung 1947: 7). Det er uklart om Waley faktisk var direkte inspireret af Wilhelm og Jungs brug af ordet yoga i deres udgivelse nogle år tidligere, eller den engelske oversættelse af den. Waley var dog både bekendt med Wilhelms arbejde og involveret i oversættelsen af det til engelsk. Det er uklart om Wilhelm selv kendte Waley personligt, men Cary Baynes takker i forordet til sin engelske oversættelse af Wilhelms oversættelse Waley for hans hjælp med transskription af kinesiske tegn, så Waley har med stor sandsynlighed haft adgang til både den udgivede tyske og den uudgivede engelske oversættelse af Taiyi Jinhua Zongzhi i præcis samme periode hvor han selv arbejdede med sit manuskript til The Way and Its Power.

Waley bruger generelt i sit appendiks til denne bog sanskrit-afledte ord som for eksempel asana, yogi, yoga og det arabisk-afledte akir $^{9}$ til at beskrive og diskutere kinesiske kropsteknikker. Til sammenligning er det interessant, at de franske Kina-missionærer Pierre-Martial Cibot (1727-1780) og Jean Joseph Marie Amiot (1718-1793) i 16-binds værket Mémoires Concernant l'Histoire, les Sciences, les Arts, les Moeurs, les Usages, etc., des Chinois: par les Missionaires de Pékin (1776-89), som mig bekendt er den tidligste europæiske udgivelse der omtaler daoistiske krops- og åndedrætsteknikker, valgte

\footnotetext{
8. Et filosofisk samlingsværk fra Han-dynastiet med daoistiske, konfucianske og legalistiske elementer.

9. Fakir stammer fra det arabiske ord faqīr men er givetvis gledet ind i engelsk via urdu, bengali, eller hindi. Særligt hindi-betydningen synes, at have inspireret den engelske brug af ordet.
} 
at beskrive det de kaldte Cong Fou ${ }^{10}$ som pneumatiske manipulationer af torsoen. ${ }^{11} \mathrm{Ci}$ bot og Amiots diskussion af disse teknikker, som findes i sektionen «Notice du Cong Fou des Bonzes Tao Sée» (notits om de daoistiske munkes cong $f u)^{12} \mathrm{er}$, i lyset af deres katolske baggrund, overraskende mekanistisk og uden analogier til hverken kristne eller indiske begreber (Thykier Makeeff 2020). Det kan umiddelbart virke overraskende, at to katolske missionærer beskriver fænomenet med mekanistiske referencer i et så tidligt værk, mens en-i øvrigt ikke-kristen (Waley var af Ashkenazi-slægt og hed oprindeligt Schloss) — filolog ca. 150 år senere bruger et væld af indiske termer i et forklarende appendiks til en kinesisk kildetekst. Cibot og Amiots nøgterne brug af referencer til pneumatik må forstås i lyset af inspirationen fra både encyklopædismen (som deres enorme værk var del af) og den gryende industrielle revolution der foregik omkring dem (hvor pneumatik og pumper spillede en stor rolle) og kunne måske sammenlignes med nutidens hyppige sammenligning mellem hjerner og computere.

Waleys terminologi er dog noget mere overraskende. Han vælger nemlig i indledningen til sin oversættelse af Daodejing, at introducere og forklare adskillige kinesiske begreber (f.eks. tian, qi, shen, de, dao), mens han uden forklaring diskuterer andre kinesiske begreber med indiske termer uden at angive de oprindelige kinesiske ord. Det virker nærliggende, at fortolke denne begrebsoversættelse som et forsøg på en håndsrækning til læseren. Waley levede og skrev trods alt $i$ en periode hvor ganske få englændere kendte særlig meget til kinesisk specialterminologi, mens nogle indiske begreber var mere alment kendte, både på grund af britisk kolonihistorie og indologiens noget længere historie og bredere appel end sinologiens. Men også fordi yoga- og fakir-relateret terminologi gennem en årrække var blevet populært udbredt både af tryllekunstnere (Lamont 2005), okkultister som Aleister Crowley og på grund af udbredelsen af hathayoga gennem udøvere og lærere som Adonia Wallace og grundlæggeren af Women's League of Health \& Beauty, Mary Bagot Stack (1883-1935).

At Waley skulle vælge yoga-relaterede begreber som folkelige oversættelser af kinesiske termer er altså måske ikke så overraskende, men må forstås på samme måde som Cibot og Amiots referencer til pneumatik, som tidstypiske, almenkendte begreber. Det overraskende ved Waleys begrebsoversættelse ligger i, at han overhovedet ser et behov for at oversætte kinesiske begreber. I forordet til sin Daodejing-oversættelse-altså inden indledningen, hvor han diskuterer kinesisk terminologi og inden appendikset hvor han bruger indiske begreber-kommer han nemlig med en programerklæring for sin tilgang til oversættergerningen. Waley understreger at hans oversættelse ikke er litterær, men fokuseret på hvad originalteksten siger: «I want to make it clear that this translation

10. De øvelser Cibot og Amiot beskriver som Cong Fou er, at dømme ud fra deres illustrationer en slags daoyin som portrætteret på Daoyintu-klædet fra grav nr. 3 i Mawangdui.

11. For en diskussion af Cibot og Amiots se også: Habersetzer og Habersetzer 2004: 121-122.

12. Min oversættelse. 
of the Tao Tê Ching is not 'literary'; for the simple reason that the importance of the original lies not in its literary quality but in the things it says, and it has been my one aim to reproduce what the original says with detailed accuracy» (Waley [1934] 1977: 14 , kursiv i original).

Waley skelner mellem to typer oversættelsespraksis som han kalder «historical» og «scriptural». Den første beskriver han som oversættelsen der: «set out to discover what such books meant to start with» mens den anden er oversættelsen der «aim only at telling the reader what such text means to those who use it today» (Waley [1934] 1977: 13). Waley betragter sin egen tilgang som «historical» og nævner Richard Wilhelms version af Yijing — som han i øvrigt roser-som et eksempel på en «scriptural» tilgang. Det bemærkelsesværdige ved Waleys oversættelse er altså, at han på den ene side insisterer på at forsøge at give læseren så ren en adgang til den oprindelige betydning af teksten, mens han på den anden side gør dette med en blanding af kinesiske begreber og terminologi hentet fra blandt andet Indien. Waley bruger dog noget sideplads på, at diskutere mulig påvirkning mellem kinesiske og indiske kropsteknikker og meditation, men det bliver ikke klart forklaret hvordan hans begrebsoversættelse hænger sammen med dette. Han fremhæver i sit forord til Daodejing adskillige andre europæiske sinologer og understreger særligt den samtidige Henri Maspero som en forsker han ganske ofte har udtrykt uenighed med, selvom han anerkender Masperos generelle arbejdes værdi (Waley [1934] 1977: 15). Henri Maspero nævner mig bekendt ikke i sit arbejde yoga som et overførbart begreb til at beskrive kinesiske teknikker, selv om en nyere oversættelse af hans arbejde beskrives af forlaget som «extensive investigation of yoga-like procedures of nutrition, breathing exercises, and sexual techniques». ${ }^{13}$ I modsætning til Waley mente Maspero ikke, at eksempelvis Laozi og Zhuangzi anvendte særlige kropslige teknikker. Maspero skrev dog udførligt om legems- og åndedrætsøvelser indenfor daoisme, men i modsætning til Waley, som omtalte sådanne som yoga og self-hypnosis, brugte Maspero betegnelserne gymnastique générale og gymnastique de la respiration.

Efter Wilhelm, Jung, Baynes og Waley er der tilsyneladende en relativt lang periode hvor ord som yoga og yogic ikke anvendes i sinologiske udgivelser, hvilket jeg på nuværende tidspunkt ikke har nogen god forklaring på. Dog finder vi et muligt missing link i en udgivelse fra 1963, nemlig The Wisdom Of The Serpent: The Myths Of Death, Rebirth And Resurrection, en antologi udgivet af Alan Watts i samarbejde med Joseph Lewis Henderson, en læge og jungiansk psykoterapeut og etnologen og jungianeren Maud Oakes. Denne udgivelse indeholdt både dele af Wilhelm og Waleys oversættelser og har muligvis medført en fornyet interesse i deres arbejde på området.

13. Se: https://www.quirinpress.com/ISBN/9781922169044.html (alle onlinekilder jeg nævner i denne artikel er sidst besøgt 21 november 2021. Jeg anfører af pladshensyn ikke dette i hvert individuelle tilfælde). 
Det næste eksempel jeg har kunnet finde er i sinologen Anna Seidels Taoismus: Die inoffizielle Hochreligion Chinas (1990). Seidel inddrager uden yderligere forklaring yoga-udøvere i en sætning der ellers omhandler det kinesiske begreb qi: «Was ch'i genau ist, darüber warden die Sinologen, die Naturwissenschaftler und die Adepten chinesischer Meditation und Yogapraktiken noch lange diskutieren» (Seidel 1990: 6). Det fremgår af konteksten at Seidel implicit antyder at $q i$ er sammenligneligt med sanskritbegrebet prana, men nogen videre diskussion af dette bliver det ikke til. Som læser får man indtryk af, at hun antyder, at somatiske praktikker, såvel som terminologi fra Indien og Kinas historie, er sammenlignelige i en sådan grad, at udøvere af disse praktikker har gensidig indsigt $\mathrm{i}$ hinandens teorier om legemelige og kosmiske energier. Det er dog uklart om dette skal fortolkes som udtryk for at Seidel betragter begge disse som del af en slags philosophia perrennis eller der sigtes til historisk påvirkning mellem indisk og kinesisk kropskultur. Et eksempel på, at brugen af yoga som begreb til at beskrive kinesiske legemsøvelser har bevæget sig fra sinologien til den bredere religionsforskning er Christopher M. Moreman, der i Beyond the Threshold: Afterlife Beliefs and Experiences in World Religions omtaler praktikker, der beskrives af Zhuangzi, som «yoga-like body postures». Moreman læner sig her tilsyneladende op ad Henri Maspero, som han også citerer på samme side (Moreman 2010: 147). ${ }^{14}$

Den mest udbredte brug af ordet yoga i sinologien er i begrebet sexual yoga. Sinologen Douglas Wile er en af flere forskere der bruger dette begreb til at beskrive historiske kinesiske seksuelle teknikker (fangzhongshu). Hans oversættelse af et udvalg af historiske tekster udkom under titlen Art of the Bedchamber: The Chinese Sexual Yoga Classics Including Women's Solo Meditation Texts i 1992. Seks år senere udkom sinologen Stephen Eskildsens bog Asceticism in Early Taoist Religion der ligeledes bruger begrebet sexual yoga til at beskrive daoistiske kropsteknikker, uden nogen videre kritisk diskussion af eller begrundelse for låneordet yoga. Eskildsen angiver, at det er det kinesiske begreb fangzhongshu han oversætter med sexual yoga (Eskildsen 1998: 16). En Ph.D. afhandling fra SOAS, Sex And Immortality: A Study of Chinese Sexual Activities for Better-Being (2004) af Sumiyo Umekawa demonstrerer dog at det er fuldt ud muligt, at diskutere fangzhongshu uden at bruge det noget uklare begreb sexual yoga. I Umekawas afhandling optræder ordet yoga således kun fire gange, alle i bibliografien, som del i titler af andre forfattere. Selv om der er nogen tendens til at bruge de kinesiske begreber, fremfor at oversætte dem, er sexual yoga dog stadig i brug. Eskildsen brugte det senest i 2004 om fangzhongshu (2004: 82) og Douglas Wile brugte begrebet i artiklen «Debaters of the Bedchamber: China Reexamines Ancient Sexual Practice» (2018). Endelig

14. Det er dog uklart hvor Moreman har begrebet «yoga-like» fra, da det, som nævnt ovenfor, så vidt jeg kan se ikke optræder i Masperos arbejde men nævnes på bagsiden til Taoism and Chinese Religion (2014) den engelske oversættelse af hans bog Le Taö̈sme et Les Religions Chinoises der blev udgivet posthumt i 1971, samt på forlagets hjemmeside (se note 13). 
bør det også nævnes, at socialantropologen og tibetologen Geoffrey Samuel i et kapitel fra 2013 introducerer begrebet internal yogic structure som et argument for, at netop kinesisk seksuel praksis kunne have påvirket de indiske ditto:

This early Chinese material is more explicit and detailed about what we could call the internal yogic structure of the subtle body and its connection with sexual practices than anything found in India until many centuries later, which raises the possibility that these practices may have been imported from China (Samuel 2013: 43).

Selv om Samuel ikke omtaler fangzhongshu som sexual yoga, mener jeg det kan være meningsfuldt, at inkludere ham i gruppen af forskere der har medvirket til, at udbrede og opretholde ideen om at kinesisk yoga skulle være et anvendeligt videnskabeligt begreb i betragtning af den nære semantiske relation mellem ordene yoga og yogic. Som jeg vil vise i det følgende afsnit findes der dog også en lang, kompleks og i nogen grad parallel tradition for, at skrive om kinesisk yoga i terpeutiske og nyreligiøse håndbøger.

\section{KineSISK YogA I (KROPS-)TERAPEUTISKE HÅNDBØgER}

Det følgende afsnit er en gennemgang af hvordan ordet yoga er blevet brugt i ikke- akademiske bøger der omhandler kinesiske legemsøvelser. Jeg har valgt at kalde disse for kropsterapeutiske håndbøger, der overordnet set henvender sig til læsere der er interesserede i praktisk, såvel som teoretisk, historisk og mytologisk information—og gør dette med en betoning af vejledninger i hvordan legemsøvelser, meditative metoder og diæt kan anvendes som en form for terapi. Min litteraturgennemgang er ikke en udtømmende oversigt, men jeg mener at have inkluderet størstedelen af de vigtigste engelsksprogede bøger fra starten af 1970erne, hvor denne litterære niche-genre for alvor begyndte og op til nutiden. ${ }^{15}$ Jeg har i store træk valgt, at præsentere bøgerne kronologisk, men i visse tilfælde, for eksempel hvor samme forfatter har udgivet flere relevante bøger, eller der findes interessante oversættelser, afviger jeg fra denne tilgang.

Efter Wilhelm, Jung, Baynes og Waley er det tidligste eksempel jeg har fundet på brugen af yoga-begrebet i beskrivelsen af kinesiske kropsteknikker Lu K'uan Yüs (Charles Luk) bog Taoist Yoga: Alchemy \& Immortality ([1970] 1973). Lus bog blev genudgivet flere gange og blev i 1980erne promoveret i yoga-miljøet i USA gennem reklamer i Yoga Journal. ${ }^{16}$ Bogen er en oversættelse af Zhao Bichens værk Xingming Fajue Mingzhi, hvilket Lu oversætter til The Secrets of Cultivating Essential Nature and Eternal Life.

15. Det skal her nævnes, at jeg af pladshensyn har udeladt, at diskutere bøger eller online kilder der bruger begrebet Taoist tantra og lignende termer. Dette er udelukkende af pladshensyn. Der er en næsten lige så rigt kildemateriale om kinesisk tantra som der er om kinesisk yoga. Af samme årsag nævner jeg kun yin yoga ganske kort, selvom der her også er et enormt kildemateriale at dykke ned i.

16. Blandt andet i Yoga Journal Sep-okt 1985: 65 
Taoist Yoga, Alchemy and Immortality. Zhao Bichen (født 1860) var daoist og hans manuskript beskriver neidan-metoder. I forordet til sin oversættelse af Bichens tekst nævner $\mathrm{Lu}$, at udgivelsen skyldes, at han er blevet kontaktet af «Western readers who have practised Indian yoga and are also interested in studying its Chinese equivalent» (Lu [1970] 1973: xi). I selve bogen anvendes yoga-begrebet dog ikke i nogen særlig grad, ligesom det ikke forekommer i indekset, hvilket kunne antyde, at brugen af ordet yoga i titlen måske var motiveret af forlagets interesse $\mathrm{i}$ at gøre bogen attraktiv for potentielle købere i yoga-miljøet. Det er interessant, at bemærke, at Lu, på trods af, at teksten han oversætter er fra det 20 århundrede, i samme forord beskriver teksten som «ancient» (Lu [1970] 1973: xviii).

Nogle få år senere i 1978 udkom John Blofelds Taoism: The Road to Immortality, hvor Blofeld blandt andet i kapitel otte omtaler neidan som Taoist yoga og yoga of immortality. Samme år udkom Stephen T. Changs The Book of Internal Exercises (1978) (udgivet i samarbejde med psykologen Richard C. Miller) og i 1982 udkom Chang og Miller med bogen Chinese Yoga: Internal Exercises for Health and Serenity of Body and Mind. ${ }^{17}$ Chang og Millers første bog udkom i 1984 i dansk oversættelse under titlen $\mathrm{Ki}$ nesisk Yoga: Taoistiske Energiøvelser. Den danske udgave var oversat af Swami Deva Satyarthi (Jens-Erik Risom) der i 1970erne var discipel af Bhagwan Shree Rajneesh og aktiv i OSHO-bevægelsen. Øvelserne i bogen synes at være hentet fra forskellige steder. Forfatterne tilkendegiver at de kinesiske øvelser de omtaler som kinesisk yoga er såkaldt qigong. Hoveddelen af bogen fokuserer på det der omtales som «energiøvelser» inspireret af dyrene hjort, trane og skildpadde. Det er uklart hvor inspirationen til disse øvelser kommer fra, men en del af materialet synes, at være direkte inspireret af hathayoga, i hvert fald koreografisk. Til gengæld minder øvelserne i bogen ikke meget om de oldkinesiske kropsteknikker der almindeligvis omtales som dyreøvelser, nemlig de såkaldte wuqinxi (ofte oversat til engelsk som five animal frolics), der populært tilskrives den kinesiske læge Hua Tuo, der levede under det sene østlige Han-dynasti.

I 1983 udkom britisk-kinesiske Chee Soos Taoist Yoga: The Chinese Art of K'ai Men. En tidligere version af bogen var allerede blevet udgivet i 1977 på forlaget Gordon \& Cremonesi under titlen The Chinese Art of K'ai Men, men i 1983 udkom den reviderede version i paperback på The Aquarian Press under titlen Taoist Yoga, mens den oprindelige titel nu fungerede som undertitel. Bogen blev udgivet igen i 1986 under titlen The Taoist Ways of Healing: The Chinese Art of Pa Chin Hsien. De øvelser Soo i bogen kalder yoga hedder på mandarin kai men (bogstavelig talt åben dør eller at åbne døren): «This Taoist art is generally referred to as Taoist yoga in the western world. Translated it simply means Open Door ( $\mathrm{K}^{\prime}$ ai Men), although during its long history it has also been known as Ho Ping (Unity) and Ho Hsieh (Harmony)» (Soo 1986: 125). Kai men øvel-

17. Stephen T. Chang hævder på sin hjemmeside at være Ph.D. i medicin, filosofi og teologi, samt, at have to uddannelser i jura. Se: http://www.thegreattao.com/html/founderfoundation.html 
serne stammer ifølge Soo fra dennes lærer Chan Kam Lee og Soo kategoriserer dem som neigong (indre arbejde). Soo understreger, at han bruger ordet yoga som en måde at oversætte begreber på, fordi det er den udbredte måde at omtale daoistiske kropsteknikker på. Men samtidig betoner han, at det er en utilstrækkelig oversættelse, da han betragter yoga som gymnastiske bevægelser, mens kai men er indre arbejde: «From a spectators view you would say it was yoga, but that's where the similarity ends, for this is all internal» (Soo 1986: 125).

Samme år, i 1983 udkom også Mantak Chias Awaken Healing Energy Through the Tao. I den tyske oversættelse fra 2005 udkom Awaken Healing Energy Through the Tao under titlen Tao Yoga: Praxisbuch zur Erweckung der heilenden Urkraft Chi. Begrebet Tao Yoga blev igen brugt i de tyske oversættelser af Mantak Chias bøger Taoist Secrets of Love: Cultivating Male Sexual Energy (1984)—der på tysk udkom i 2008 som Tao Yoga der Liebe: Der Weg zur unvergänglichen Liebeskraft - og Healing Love Through the Tao: Cultivating Female Sexual Energy fra 1986, der på tysk udkom i 2010 under titlen Tao Yoga der heilenden Liebe: Der geheime Weg zur weiblichen Liebesenergie. Denne sidste bog er iøvrigt højst sandsynligt den tidligste kilde i engelsksproget litteratur til fænomenet yoni eggs, et redskab til vaginal træning, som i de seneste år er blevet populariseret af Gwyneth Palthrows Goop Lab. ${ }^{18}$ Mantak Chia er sandsynligvis den mest kendte (og bedst sælgende) forfatter af bøger om kinesisk-inspirerede kropteknikker i det internationale terapeutiske miljø. Ifølge hans eget udsagn har han en baggrund i kundaliniyoga, men størstedelen af hans materiale lader til at være baseret på kinesisk kampkunst og alkymi (neidan). Chias måde at bruge yoga-begrebet på er altså en kombination af oversættelse og sammenblanding af indisk og kinesisk terminologi, som i øvrigt også kommer til udtryk i hans brug af ordet tantra til at beskrive seksuelle teknikker der i hvert fald i nogen grad er inspireret af historiske kinesiske metoder. Han beskriver ${ }^{19}$ selv forholdet mellem yoga og daoistiske kropsteknikker således:

Like meditional Indian yoga. Taoist Esoteric Yoga cultivates the subtle life force its Indian counterpart, Taoist yoga recognizes various kinds and levels of chi. The goals of both systems are the same spiritual growth and ultimately, enlightenment. In other ways, however, Taoist yoga differs from the Indian system. For one thing Taoists do not see the body and its pleasures as maya, illusion. But rather as a valuable storehouse of energy and impulses, Physical pleasure is thus not to be transcended immediately, but

18. Mantak Chia skrev i øvrigt i 2019 forordet til Lilou Macés The Yoni Egg: Reveal and Release the Sacred Feminine Within.

19. Denne tekst er sprogligt mangelfuld, men jeg citerer den præcis som den fremstår på Chias hjemmeside. 
first cultivated and utilized, and then transcended only in the final stage of development. ${ }^{20}$

Chias brug af yoga-begrebet dækker over flere kategorier af kinesiske øvelser, der inkluderer en type stående meditation kaldet zhan zhuang, men han fremhæver, at han betragter neidan som den vigtigste gruppe af teknikker: «The most advanced practices of Taoist yoga, known in traditional texts as 'internal alchemy' $[\ldots] \gg .{ }^{21}$ Chias bøger genudgives og oversættes flittigt og han udbreder også sin distinkte fortolkning af blandt andet neidan og fangzhongshu. Desuden er hans begreb Taoist Yoga også blevet videreudviklet af hans elev Eric Steven Yudelove, der i 2000 udgav bogen Taoist Yoga and Sexual Energy: Transforming Your Body, Mind, and Spirit. Chia og hans tilknyttede undervise$\mathrm{re}^{22}$ bruger også begrebet Tao Yoga ${ }^{\circledR}$ som blev trademark-registreret i $2007 .{ }^{23}$

Udover Mantak Chia, er Eva Wong en af de forfattere hvis bøger om kinesiske kropsteknikker har haft størst indflydelse i den engelsksprogede verden. Mens Chias udgivelser i store træk er hans egne originale værker (inspireret af allerede eksisterende materiale), der fungerer som del af hans bredere strategi som underviser og nyreligiøs karismatisk leder og forretningsmand, er Eva Wong primært oversætter af historiske kinesiske kildetekster, selv om hun også har skrevet populære indføringer i historisk materiale. Wong har især udgivet oversættelser indenfor waidan og neidan, som ofte oversættes som henholdsvis indre og ydre alkymi. Særligt to af Wongs oversættelser er interessante for denne artikel, da de begge bruger begrebet yoga, men om to forskellige, men beslægtede fænomener. Harmonizing Yin and Yang - A manual of Taoist Yoga: internal, external (1997) er en oversættelse af Taixuanjing (Det Højeste Mysteries Klassiker), en tekst skrevet af den konfucianske forfatter Yang Xiong i de sidste år af det vestlige Han-dynasti (omkring år 2 e.v.t.) som kun er overleveret i en kommenteret version fra Jin-dynastiet (2-5 årh. e.v.t.). Wong bruger ikke ordet yoga i selve oversættelsen, men omtaler nogle få steder i indledningen «yogic postures» som en del af pensummet $\mathrm{i}$ neidan, sammen med det hun kalder «meditation» og «calisthenics». Wong bruger også ordet yoga til at omtale seksuelle øvelser i Holding Yin Embracing Yang Three Taoist Classics on Meditation Breath Regulation Sexual Yoga and the Circulation of Internal Energy fra 2005. Denne bog indeholder oversættelser af tre kildetekster fra henholdsvis Ming- og Qing-dynastiet; Lu XiXings (1520-1606) Xuanweilun (Traktat om den Mystiske Kropsåbning) samt Li Xiyues (1806-1856) to forelæsninger Daojiaotan (Diskussion af Tao-hulningen) og Sanjubizhi (De Tre Hjuls Hemmelige Loere).

En anden brug af yoga-begrebet i kombination med referencer til kinesisk historie finder vi i adskillige bøger fra de seneste 10 år. Den australske akupunktør og yoga-

20. Se: https://www.mantakchia.com/taoist-esoteric-master-chia/

21. Se: https://www.mantakchia.com/taoist-esoteric-master-chia/

22. Se blandt andet: https://taoyoga.info/oghttps://taoyoga.es/taoist-yoga

23. Se: https://tmsearch.uspto.gov/bin/showfield?f $=$ doc\&state=4810:rlpm $3 \mathrm{~h} .2 .2$ 
lærer Michael Hetherington udgav i 2014 The Complete Book of Oriental Yoga: Hatha and Taoist Yoga For The Seasons, der samtænker og kombinerer kinesiske og indiske kropsmodeller og -teknikker. Det samme gør sig gældende i nordamerikanske Lee L. Herreras ${ }^{24}$ Meridian Systems Yoga: A Gentle \& Accessible Method That Combines Yoga $\&$ Traditional Chinese Medicine (2015) og i Camilo Sanchez' system Daoist Meridian Yoga. Dette system, som han beskriver i bogen Daoist Meridian Yoga: Activating the Twelve Pathways for Energy Balance and Healing fra 2016, har han konstrueret på baggrund af sin tid som sannyasin-asket i Satyananda Ashram i Indien mellem 1982 og 1985 og sine senere studier i akupunktur og kinesisk massage, samt kinesisk kampkunst og qigong. Ligeledes finder vi i den nordamerikanske alternative behandler Cinamon Kimbroughs Interactive Meridian Yoga Poses: To Assist in Learning Traditional Chinese Medicine Meridians and Essential Acupuncture Point Categories (2020) et godt eksempel på blandingen af meridianteori og yoga-øvelser. Fælles for alle disse bøger er, at de i større eller mindre grad tager udgangspunkt i legemsøvelser inspireret af hathayoga men udvikler det teoretiske grundlag for at forklare disse øvelser, ved at tilføje perspektiver fra traditionel kinesisk medicin (TCM). Til gengæld er det interessant, at bemærke, at disse udgivelser synes at adskille sig fra de tidligere nævnte bøger, ved ikke at omtale kinesiske øvelser og daoisme som en form for yoga men ved i stedet, at kombinere hathayoga med meridianteorier og i nogen grad at betragte chakra- og meridiansystemerne enten som udtryk for en fælles bagvedliggende virkelighed, eller som komplementære systemer der i kombination giver særlige fordele eller forbedret forståelse af en antydet bagvedliggende kropslig og energetisk virkelighed.

\section{KINESISK YOGA ONLINE}

Udbredelsen af ideer om daoistisk yoga, meridian yoga, yin yoga eller andre variationer over temaet kinesisk yoga har i de seneste år også fundet sted gennem websites, sociale medier og online videoer. Denne type fortolkninger repræsenterer et omfattende og varieret kildemateriale og jeg har af pladshensyn valgt, kun at fremhæve et begrænset udvalg for, at illustrere hvor udbredt og heterogent dette fænomen er. Den vide udbredelse af ideen om kinesisk yoga ser vi blandt andet demonstreret i, at Taoist yoga har sit eget opslag i det populære online yoga-opslagsværk Yogapedia.com, der beskriver fænomenet således:

Taoist yoga is a type of yoga which combines the ancient Indian traditions with the Chinese theories of energy maps of the body. It is generally considered to be a modern hybrid of the two systems. This combination is

24. Se: https://www.msy.yoga/ 
thought to enhance the benefits of yoga as well as provide deeper insights into how the body works. ${ }^{25}$

Det er interessant, at Yogapedia.com bruger betegnelsen Taoist yoga men i store træk beskriver den syntese af yoga-øvelser og kinesisk medicinsk teori, som i flere af de bøger jeg gennemgår ovenfor beskrives som meridian yoga eller lignende. Dette er et eksempel på at betydningen af begrebet Taoist yoga har udviklet sig fra 1970erne og 80ernes kropsterapeutiske håndbøger om kinesiske legemsøvelser. Denne forståelse af ordet er dog stadig i brug, men ofte hos undervisere med en baggrund i kinesisk kampsport eller meditation. Dette ser vi eksempelvis hos online kursusplatformen Udemy.com, der tilbyder Taoist yoga. Udemys kursus består af en kombination af øvelser fra qigong og hathayoga og undervises af den tidligere Hare Krishna-tilhænger Heng Ni. ${ }^{26}$ Samme kursus udbydes også af samme underviser gennem kursusplatformen skillshare.com. ${ }^{27}$ Heng Ni, hvis borgerlige navn er Todd Grube, er en svensk bosat, nordamerikansk yogalærer og kampsportsudøver, der har studeret under yin yoga grundlæggeren Paulie Zink og hans elev Paul Grilley. En lignende brug af Taoist yoga finder vi hos kampsportsog meditationsunderviseren Bruce K. Frantzis ${ }^{28}$, der ligesom Grube og Zink har en baggrund i både kinesisk kampkunst og hathayoga og kombinerer disse i sin Taoist yoga. Ligesom hos Grube, er indholdet her overvejende kinesisk inspireret. ${ }^{29}$

Den varierende brug af ordet yoga til at beskrive kinesiske kropsteknikker, som den tidlige periode af den kropsterapeutiske bibliografiske gennemgang ovenfor demonstrerede, afspejles også på internettet. Der er således eksempler på, at Taoist yoga kategoriseres som identisk med yin yoga eller flow yoga og beskrives som en kombination af oldkinesisk daoyin og hathayoga ${ }^{30}$ eller bruges som et paraplybegreb til at beskrive både siddende og liggende meditation, samt stående zhanzhuang og den seksuelle træning fangzhongsh $u^{31}$ og endelig bruges begrebet Daoist yoga af nogle synonymt med neidan yoga - en reference til den kinesiske neidan-tradition. ${ }^{32}$ Udover markedsføringen og italesættelsen af kinesisk yoga gennem websites og online-kurser, findes der på sociale medier som Facebook og Instagram, samt videodelingsplatforme som YouTube og Vimeo et væld af varierende fortolkninger og formidlinger af dette fænomen. Jeg vil

25. https://www.yogapedia.com/definition/6612/taoist-yoga

26. https://www.udemy.com/course/taoist-yoga

27. https://www.skillshare.com/classes/Taoist-Yoga-An-Introduction-for-All-Levels-with-Heng-Ni/ 984543465

28. https://www.energyarts.com/taoist-yoga/

29. Se blandt andet videoen «Taoist Longevity Breathing Yoga» (2010): https://www.youtube.com/ watch?v=5O1NgfVIpQU

30. https://www.wise-geek.com/what-is-taoist-yoga.htm

31. https://layoga.com/practice/yoga/5-categories-of-taoist-yoga-meditation/

32. https://neidanandyoga.com/daoist-yoga-1 
af pladshensyn i denne artikel begrænse mig til, at præsentere et kort udvalg af videoer fra YouTube, som eksempler på innovation og variation indenfor dette emne.

Et glimrende eksempel på briccolage er Yoqi, et terapeutisk system konstrueret af Marisa Cranfill. ${ }^{33}$ Yoqi beskrives af Cranfill som «mindfulness in motion» og er ifølge hendes udsagn en kombination af yoga, qigong, buddhisme og thailandsk shamanisme. Cranfill er yderst aktiv på YouTube, hvor hun deler professionelt producerede videoer med øvelser under titler som «Aroma Qigong to Center Your Energy», "Yin Yoga for Happy Kidneys» og «Qi gong: Drawing Down the Heavens Tutorial». ${ }^{34}$ Mange af Cranfills videoer er blevet set mere end 100.000 gange og nogle adskillige millioner gange, hvilket i kombination med hendes store aktivitet som underviser i workshops og online kurser må fortolkes som en indikation på, at der er stor interesse i øvelser der ligger i krydsfeltet mellem yoga og qigong. ${ }^{35}$ Yoga-læreren Mariska Gunsing fra Nederlandene, der på sin YouTube-kanal blandt andet beskriver sine videoer som «Alan Watts Themed» byder på endnu en variation af kinesisk yoga ${ }^{36}$ I to undervisningsvideoer fra 2020 med titlerne «Introduction to Taoist Yoga» og «Taoist Yoga - Self massage» fortæller hun beskueren, at det materiale hun underviser i stammer fra «ancient China». I beskrivelsen til den ene video kan vi dog læse, at øvelserne er designet af den japanske shiatsu-terapeut Shizuto Masunaga (1925-1981). Gunsings undervisningsvideoer er et godt eksempel på en sammenblanding af elementer fra forskellige perioder og steder i asiatisk historie og den nyere amerikanske reception (gennem f.eks. Alan Watts), hvilket kunne fortolkes som et udtryk for, at hun (og potentielt også hendes klienter) abonnerer på ideen om (østlig) philosophia perrenis. På sin hjemmeside reklamerer Gunsing også med, at hun kan oversætte «Taoist, Zenbuddhist \& Yogic philosophy into simple life hacks for physical \& mental health» og hendes tilgang til materialet som udtryk for samme underliggende sandhed undertreges også ved, at hun afslutter sin «Introduction to Taoist Yoga» (2020), bestående af øvelser sammensat af en japansk shiatsu-terapeut i det 20. århundrede, som hun undertiden omtaler med navne på tilsvarende øvelser fra engelsksproget hathayoga-terminologi med en meditation og historielæsning. Gunsing læser her en kort tekst højt, som hun introducerer som en «Daoist story» men som ikke har noget forlæg i Daoistisk litteratur. ${ }^{37}$ I stedet er der sandsynligvis tale om en anonymiseret, forvansket version af en Zen-fortælling om krigeren Matajuro Yagyu der står i lære hos sværdfægteren Banzo på Futara-bjerget - en fortælling der stammer fra værket Shasekishu fra Kamakura-perioden (1185-1333) og blev populær udenfor Japan gennem

33. https://www.yoqi.com/

34. https://www.youtube.com/c/yoqi/featured

35. I skrivende stund (maj 2021) er hendes video «Daily Qigong Routine» blevet vist 2.474 .365 gange.

36. http://www.mariskagunsing.com/index.php/nl/

37. https://www.youtube.com/watch? $\mathrm{v}=0 \mathrm{~L} \ln C$ nuj 190 
Rinzai-munken Nyogen Senzakis (1876-1958) engelske oversættelse fra starten af det 20. århundrede (Senzaki 1919).

Udover videoer der aktivt promoveres som omhandlende kinesisk yoga af de der selv medvirker i videoerne, findes der også eksempler på materiale af ældre dato, der uploades på internettet uden tilladelse under nye titler, der indskriver deres indhold i feltet kinesisk yoga. En ældre kinesisk undervidnings-dvd omhandlende en variation af massageteknikken gu sha, findes eksempelvis uploadet (2008) under titlen «Taoist Yoga Closing Body Massage». Denne video er blevet set over 160.000 gange. ${ }^{38}$ Endelig findes der også eksempler på undervisere der tilsyneladende bruger adjektivet «Taoist» for at give deres undervisning i hathayoga en konkurrencefordel. Dette er sandsynligvis tilfældet med den indiske YouTuber Healthyhamesha der via sin kanal underviser i hathayoga (varianten poweryoga) uden nogen særlig koreografisk inspiration eller forklaringsmodeller der involverer teori fra kinesisk materiale. ${ }^{39}$ HealthyHamesha kalder sit system «Taoist Power Yoga» men på nær nogle ganske få bevægelser der synes, at være inspireret af kinesisk kampkunst, er hans pensum baseret på hathayoga .

\section{SAMSPILLET MELLEM AKADEMISKE, NYRELIGIØSE OG TERAPEUTISKE} MILJØER

I 2014 udgav religionforskeren og esoterikeren Lee Irwin $^{40}$ artiklen Daoist Alchemy in the West: The Esoteric Paradigms fra 2014. Irwins fokus er et andet end mit, nemlig alkymi og selv om denne artikel på mange måder er nyttig, er det problematisk, at han på trods af en grundig gennemgang af adskillige nyreligiøse og terapeutiske håndbøger der omtaler daoistisk yoga, selv ukritisk bruger det samme begreb i sin gennemgang af materialet. ${ }^{41}$ Til trods for den ureflekterede sammenblanding af emic og etic terminologi, er Irwins artikel dog vigtig, da den placerer den moderne reception af daoisme og kinesiske legemsøvelser i den engelskprogede verden i en historisk kontekst. Irwin påpeger også - efter min mening med rette-hvorledes kinesisk religiøs tænkning er blevet betragtet som en slags philosophia perennis i europæisk og nordamerikansk historie. ${ }^{42}$ Irwin beskriver philosophia perennis som «the authentic, inherent core of all 'true' religious traditions» (Irwin 2014). Han sporer dette tilbage til Leibniz og fremhæ-

38. https://www.youtube.com/watch?v=mZOqPwSl2EE

39. https://www.youtube.com/user/healthyhamesha/featured

40. https://thesophiainstitute.org/profiles/dr-lee-irwin/

41. I betragtning af det betragtelige overlap mellem Irwins og mit eget studie af terapeutiske og nyreligiøse håndbøger om daoisme og kinesiske legemsøvelser, skal det i øvrigt understreges, at en stor del af min egen forskning på området forløb uafhængigt af Irwins artikel og inden han udgav den. Jeg har altså kun i meget begrænset grad ladet mig inspirere af Irwin, men har dog haft nogen gavn af hans arbejde på dette område.

42. Irwin bruger det efter min mening noget problematiske og uklare begreb «the West». 
ver også det amerikanske Theosophical Society, René Guénon, Titus Burckhardt, Julius Evola samt forskeren Toshihiko Izutsus bog Sufism and Taoism (1967) som eksempler på populariseringen af daoisme som philosophia perennis. Irwin opdeler den historiske receptionsprocess i det han kalder «three notable stages of Daoist impact on Western esotericism» og fremhæver særligt det førte stadie, karakteriseret af intellektuelle tilgange til et begrænset og tvivlsomt oversat kildemateriale uden rod i religiøs praksis, som kendetegnet ved ideen om philosophia perennis. Det andet stadie karakteriserer han som præget af interesse fra esoterikere og traditionalister og nogen grad af rituel fortolkning og sammenligning med renæssancen, mens det tredje stadie repræsenterer det materiale jeg undersøger i denne artikel. Dette stadie beskrives som begyndende med forfattere som Thomas Merton, John Blofeld og Alan Watts, den nyreligiøse interesse for daoisme, samt påvirkning gennem tilflyttende kinesiske undervisere der både underviste, oversatte og skrev bøger. Ligeledes sker der i denne periode en vækst i interessen for $q i$ gong samt taijiquan og anden kinesisk kampsport, som Irwin - efter min mening noget lemfældigt—beskriver som «related to 'internal alchemy'». Dette sidste stadie kendetegnes også ifølge Irwin ved fremvæksten af akademisk (og etnografisk) forskning af daoisme. Eftersom Irwins fokus er et andet end mit giver denne opdeling relativt god mening $\mathrm{i}$ forhold til hans artikel. Men når man som jeg udelukkende, eller i hvert fald primært kigger på det tredje af Irwins stadier og særligt hvis man forsøger, at forstå samspillet mellem akademisk, nyreligiøs og terapeutisk litteratur, tegner der sig et mere komplekst billede. Det er påfaldende, at Irwin ikke nævner Arthur Waley en eneste gang i sin artikel. Waleys oversættelse af Daodejing repræsenterer nemlig et eksempel der overskrider Irwins stadie-kategorisering. Der er tale om en klassisk daoistisk tekst som Irwin placerer i stadie et, men i Waleys omfattende kommentarer til oversættelsen finder vi, som jeg har beskrevet, et appendiks der fokuserer på praksis (Irwins stadie to og tre) og antyder tekstens indhold som udtryk for philosophia perennis (Irwins stadie et). Endelig må receptionshistorien af Waleys oversættelse i senere paperbackversioner, placeres i hvad Irwin ville kalde stadie tre. ${ }^{43}$ Irwin placerer i øvrigt også Wilhelm og Jung i stadie et, hvilket kunne kritiseres udfra de samme argumenter som jeg netop har opridset vedrørende Waley. Selv om ideen om at systematisere receptionshistorie er tillokkende, vil jeg her afholde mig fra, at gøre Irwin kunsten efter, da jeg mener emnet er for komplekst. En streng opdeling i faser eller stadier vil kun komplicere det yderligere. Jeg vil i stedet kronologisk opridse hvordan både akademiske, nyreligiøse og terapeutiske publikationer tilsyneladende har påvirket hinanden gensidigt $\mathrm{i}$ udviklingen af ideer om kinesisk yoga. Som jeg har demonstreret, kom den akademiske brug før den nyreligiøse og terapeutiske og begge findes stadig og trives. I det følgende vil jeg kort

43. Det skal nævnes, at Irwin på trods af at han opstiller sine tre stadier som kronologiske, ikke selv overholder denne kronologi i sine eksempler på stadierne. 
diskutere hvilke dynamikker der var med til, at udforme ideen om kinesisk yoga mellem disse miljøer.

Som jeg har vist, er Richard Wilhelms tyske oversættelse og C. G. Jungs kommentar til Taiyi Jinhua Zongzhi, Cary F. Baynes' engelske oversættelse af deres tekst og Arthur Waleys oversættelse af Daodejing sandsynligvis de tidligste eksempler på beskrivelsen af kinesiske legemsøvelser som former for yoga. Herefter følger en bemærkelsesværdigt lang periode på cirka tre årtier hvor begrebet ikke synes, at være i brug. Det næste eksempel vi finder er i Lu K'uan Yüs Taoist Yoga: Alchemy \& Immortality fra 1970. Yüs bog er som nævnt en oversættelse af tekster fra neidan-traditionen og falder i en vis forstand, som flere af de tidlige oversættelser af kildetekster, midt imellem kategorierne akademisk og terapeutisk håndbogslitteratur. Dette sammenfald er karakteristisk for de omtalte udgivelser fra 1970erne, både fordi flere af dem er oversættelser eller diskussioner af historisk materiale og fordi denne periode generelt bærer præg af en voksende interesse for kinesisk filosofi og daoisme, der betyder, at der er en betydelig synergi mellem oversættelsesarbejde og nyreligiøse og terapeutiske miljøer. Dette eksemplificeres også i Watts, Henderson og Oakes' genudgivelse af Wilhelm og Waleys oversættelser i The Wisdom Of The Serpent (1963). Lidt sat på spidsen, er der tale om hippier (bredt formuleret) der læser Daodejing blandt andet i Arthur Waleys oversættelse, der genudgives flittigt i billige paperbacks og akademikere som Fritjof Capra og Gary Zukav der udbreder nye ideer om daoisme som kunne karakteriseres som variationer over fænomenet philosophia perennis, med fysikken som omdrejningspunkt. Zukavs The Dancing $W u$ Li Masters: An Overview of the New Physics (1979) nævner ganske vist ikke kinesiske legemsøvelser og omtaler kun yoga ganske perifært, men Capras The Tao of Physics: An Exploration of the Parallels Between Modern Physics and Eastern Mysticism (1975) fremhæver yoga og den kinesiske kampkunst taijiquan som væsensbeslægtede:

In many forms of meditation, this silencing of the rational mind is achieved by concentrating one's attention on a single item, like one's breathing, the sound of a mantra, or the visual image of a mandala. Other schools focus the attention on body movements which have to be performed spontaneously without the interference of any thought. This is the way of the Hindu Yoga and of the Taoist Tai Chi Ch'uan (Capra 1975: 38).

Et andet sted i bogen skriver Capra, at taijiquan kombinerer «slow and rhythmical 'yogic' movements with the total alertness of the warrior's mind in a unique way» (Capra 1975: 40). Endelig bør det nævnes, at 1970erne også var en interessant periode af endnu en årsag. I 1973 fandt arkæologer under udgravning af grav nr. 3 i Mawangdui i Changsha, hovedstaden i den kinesiske provins Hunan, det såkaldte daoyintu, et klæde med illustrationer af de såkaldte daoyin legemøvelser. Illustrationerne på klædet, der dateres til 168 f.v.t., er siden blevet gengivet som illustrationer i håndbøger om kinesiske legemsøvelser og klædet er blevet brugt som argument for øvelsernes lange historie. 
Det er vanskeligt at påvise en direkte sammenhæng mellem den internationale vækst $\mathrm{i}$ interesse for kinesiske legemsøvelser i denne periode og dette arkæologiske fund, men jeg mener det er sandsynligt, at fundet har skabt øget interesse såvel som legitimitet.

Det er interessant, at ideen om yoga som brugbart begreb efter Wilhelm, Jung Baynes og Waleys udgivelser ikke findes i sinologisk litteratur før 1990erne og måske lige så interessant er det, at det første eksempel, nemlig Anna Seidel, nævner udøvere af hathayoga og kinesisk meditation som de der har meninger om qi. Seidel forholder sig altså tilsyneadende til det moderne terapeutiske og nyreligiøse miljø i et værk der ellers omhandler religion i Kinas historie. Det er uklart om Seidel selv var del af disse miljøer, men det er et faktum, at en betydelig mængde af især neidan-studies sinologer også selv praktiserer en eller anden form for kinesisk meditation eller legemsøvelser. ${ }^{44}$ Et godt eksempel på dette er den franske sinolog og neidan-forsker Catherine Despeaux, hvis håndbog Taiji quan: Art Martial, Technique de Longue Vie (1990) udkom samme år som Seidels Taoismus: Die inoffizielle Hochreligion Chinas. Andre velkendte eksempler er sinologerne Kristofer Schipper, der tidligt i sin akademiske karriere i 1968 blev initieret i taiwanesisk Zhengyi-daoisme og i øvrigt var fortaler for taijiquan som en god metode til at forstå daoisme og Louis Komjathy, der som initieret i Quanzhendaoisme underviser i meditation gennem The Daoist Foundation, som han også er leder af. Ligeledes har sinologen Livia Kohn, en af de førende eksperter i daoistiske legemsøvelser og meditation, et parallelt forfatterskab i terapeutiske håndbøger og aktivitet som underviser i workshops i daoistiske øvelser. Kohn arrangerer i øvrigt også årligt den velbesøgte International Conference on Daoist Studies, der både består af en kombination af forskningsbaserede paneler, meditationsworkshops og besøg af initierede daoister (daoshi) fra Kina. Der er kort sagt ikke vandtætte skodder mellem miljøerne. I 1990erne ser vi også Wile og Eskildsens brug af begrebet sexual yoga om fangzhongshu. Det er en nærliggende tanke, at nogle af de nævnte sinologer, og sikkert mange flere, først stiftede bekendtskab med emnet i deres ungdom i 1970erne og 1980erne gennem den voksende mængde håndbøger og oversættelser jeg har omtalt i denne artikel. ${ }^{45}$

44. Her er det på sin plads at nævne, at jeg også selv til dels falder i denne kategori. Jeg har siden 1999 trænet de kinesiske kampkunstsystemer taijiquan, xingyiquan og baguazhang. Jeg begyndte at træne disse systemer omkring samtidig med at jeg begyndte på universitetet og var heldig at have en lærer der underviste baseret på en naturvidenskabelig tilgang til menneskelig fysiologi (fremfor de ellers i kampkunstmiljøet udbredte påstande om qi og meridianer) og en kritisk tilgang til kampkunsthistorie og mytologiserende påstande. Ligeledes har jeg i en årrække trænet hathayoga - også med en fagligt funderet kritisk tilgang. Min interesse for disse emner og mit kendskab til træningsmiljøerne skyldes altså egenprakis, men min tilgang til dem er solidt forankret i min uddannelse som forsker.

45. Seidel er født i 1938 og Wile i 1944 mens Eskildsen er noget yngre (han skrev sit speciale i 1989). 


\section{KONKLUSION}

Ideen om kinesisk yoga synes altså, at være introduceret af Wilhelm, Jung, Baynes og Waley i både sinologiske og psykoanalytiske sammenhænge i 1920erne og 1930erne og have gæret og vokset i det alternative miljø fra 1970erne til 1990erne. ${ }^{46}$ Derefter begynder ideen om kinesisk yoga igen at optræde i sinologisk litteratur og det er muligt, at denne gen-introduktion skete med påvirkning fra det alternative miljø. Endelig er det værd at nævne, at forlagsbrancherne i de repespektive miljøer kan have spillet en rolle i at promovere variationer over begrebet kinesisk yoga som en praktisk måde til at hjælpe læserforståelse, såvel som en smart marketingredskab til at låne brandingværdi fra yogamiljøet. Hathayoga var i denne periode meget mere udbredt end kinesiske legemsøvelser og ideen om kinesisk yoga kan meget vel, både i sinologisk, nyreligiøs og terapeutisk litteratur, være udtryk for oversættelsen af kinesisk specialiseret terminologi til et mere velkendt og attraktivt begreb.

Der synes at være mindst tre til tider sameksisterende måder kinesisk yoga anvendes på; ordet yoga anvendes om kinesisk materiale for at antyde en historisk forbindelse mellem Indien og Kina, for at understrege at både yoga og kinesiske legemsøvelser er kropslige udtryk for en bagvedliggende philosophia perennis, og af praktiske årsager som oversættelse af kinesiske begreber udfra den logik, at yoga ikke længere er et stykke specialiseret indisk terminologi, men er indgået i engelsk og andre sprog. Overordnet set er udbredelsen af brugen af begrebet yoga i den moderne sinologi ikke overvældende stor og har hos Wile og Eskildsen nok mest karakter af en praktisk oversættelse, mens Seidels kommentarer om yogiers kundskab om $q i$ fremstår mere kryptisk og efterlader læseren med fornemmelsen af, at det kunne være en antydning af de indiske og kinesiske kropstraditioner som udtryk for philosophia perennis. Går vi tilbage til Wilhelm, Jung, Baynes og måske særligt Waley er yoga et af mange låneord der bruges begrebsmæssigt og kigger vi nøjere efter finder vi både i ældre og nyere sinologi eksempler på potentielt problematiske oversættelser af kinesiske begreber med ord taget fra, hvad man må formode forfatterne har tænkt på som deres og læsernes egen kulturelle og sproglige sfære. Daoistiske kropsteknikker omtales også som quietism ${ }^{47}$, efterlivsforestillinger italesættes med referencer til paradiset (Loewe 1979) og der er fortsat generel enighed blandt sinologer om, at fænomenerne waidan og neidan omtales som henholdsvis indre og ydre alkymi, for at nævne et par eksempler. For nogle få år siden så vi endda hos Lusthaus et eksempel på, at yoga igen blev brugt som komparativt begreb med betydningen: «bodily disciplines, hygienic regimens, inner alchemy, breathing techniques, body maps, pursuit of physical immortality, etc» (Muller 2018).

46. Det skal dog nævnes, at andre forfattere inden Waley havde anvendt yoga på lignende måder, som oversættelse af specialiserede termer. Bl.a. skrev historikeren og teosoffen G. R. S. Mead omkring århundredeskiftet om 'the yoga of Plotinus' (1906).

47. Waley (1934) 1977: 116. 
Denne udvidelse af ords betydning, og deres overgang fra ord til begreber er en helt fundamental bestanddel af komparativitet, hvilket vi religionshistorikere ofte må forholde os til i vores arbejde. Selv udenfor den specifikt komparative religionshistorie, er dannelsen af begreber ofte nøje knyttet sammen med oversættelsen af ord fra andre sprog, dialekter eller sociolekter. Uden transkulturel begrebsdannelse er sammenligning vanskelig, men med en sådan begrebsdannelse følger ofte uønsket baggage; utilsigtede dobbelte betydninger, implicitte antydninger, eller potetielle fortolkninger om begrebers universelle gyldighed og fænomener som kan antage karakter af en antydet philosophia perennis. Der er talrige eksempler på denne oversættelse af specialiserede begreber fra fremmedsprog ved, at bruge andre specialiserede begreber fra andre fremmedsprog, der blot har en større grad af almen brugskontekst i vores egne sprog. Ord som alkymi og shaman, mana og tabu bruges stadig ligesom man stadig i ny og næ støder på brugen af ordet prcest som generel betegnelse for religiøse specialister.

Da jeg var barn, var jeg meget glad for den danske is ${ }^{48}$ der hedder Kungfu. Den blev markedsført som «karateisen» og da jeg var barn vidste jeg ikke, at der var forskel på kungfu og karate. Begge ord var fremmedartede og havde en spændende klang. Ligesom mange andre danskere lærte jeg disse ord at kende gennem Bruce Lees debutfilm, The Big Boss (1971) ${ }^{49}$, som på dansk kom til, at hedde Karatencever af Stål og gav navn til ideen om karatefilm. Selv om Lees film og mange andre såkaldte karatefilm faktisk ikke indeholdt meget af den japanske kampkunst karate, men i stedet kampkunst med oprindelse i Hong-Kong og USA, så var karate mere udbredt i Danmark end kungfu og man valgte, at oversætte kungfu med karate. Dette skete givetvis både fordi karate var bedre kendt og på grund af en underliggende idé om orienten eller det orientalske som et sammenhængende kulturelt paradigme - et fundamentalt slægtskab. Ligesom karateisen Kungfu er ideen om kinesisk yoga et udtryk for både en orientalistisk begrebssammenblanding og et forsøg på, at hjælpe forståelsen på vej ved at bruge kendte begreber, fremfor at forklare nye. Men denne tendens er også til tider et udtryk for en underliggende idé om philosophia perrennis, et grundlæggende, åndeligt, men også fysisk slægtskab, der gør det ikke bare praktisk, men også meningsfuldt, at tale om kungfu som karate, eller daoyin, neidan og fangzhongshu som yoga. Denne sag kompliceres yderligere, i og med at der ofte faktisk er tale om nogen grad af historisk påvirkning mellem fænomenerne. Karate blev udviklet på Okinawa baseret i høj grad på kinesisk kampsport ligesom der har været en lang historisk udveksling af information (og kropskultur) mellem Kina og Indien.

I tilfældet kinesisk yoga har der, som jeg har vist, været en betydelig udveksling mellem akademiske, psykoanalytiske, nyreligiøse og alternative terapeutiske miljøer, siden den moderne idé om kinesisk yoga blev introduceret af Richard Wilhelm, C. G.

48. Norsk: Iskrem; svensk: Glass.

49. The Big Boss var den europæiske titel. I USA udkom filmen under titlen Fists of Fury. 
Jung, Cary Baynes og Arthur Waley i 1920erne og 1930erne. Ordet yoga er siden blevet brugt af sinologer såvel som terapeuter og aktører i nyreligiøse miljøer, til at beskrive et væld af forskellige kinesiske legemsøvelser så som neidan, daoyin, kai men, zhan zhuang, gu sha, fangzhongshu og til at navngive nye terapeutiske tilgange med større eller mindre grad af inspiration fra historiske kropsteknikker. Et ord der i sin sanskritkontekst havde et væld af betydninger er ved sin inklusion i blandt andet engelsk, tysk, fransk, spansk, skandinaviske sprog og mange andre blevet givet endnu flere. Ligesom mana, tabu eller shaman er yoga gået fra ord til begreb og er så polyvalent, at det ikke har nogen fast betydning. Begreber som kinesisk yoga er måske nok velsmagende, men også forvirrende, foranderlige og flygtige. Ligesom karateisen Kungfu smelter de mellem vores hænder når vi bare pakker dem en smule ud.

\section{LITTERATUR}

Alter, Joseph S. 2004. Yoga in Modern India: The Body between Science and Philosophy. Princeton \& Oxford: Princeton University Press.

Alter, Joseph S. 2005. «Āyurvedic Acupuncture-Transnational Nationalism:

Ambivalence About the Origin and Authenticity of Medical Knowledge». I Asian Medicine and Globalization, redigert av Joseph S. Alter, 21-44. Philadelphia: University of Pennsylvania Press. https://doi.org/10.9783/9780812205251.21.

Alter, Joseph S. 2009. «Yoga in Asia-Mimetic History: Problems in the Location of Secret Knowledge». Comparative Studies of South Asia, Africa and the Middle East 29 (2): 213-229. https://doi.org/10.1215/1089201X-2009-005.

Amiot, Jean Joseph Marie, og Pierre-Martial Cibot. 1776-89. Mémoires Concernant l'Histoire, les Sciences les arts, les Moeurs, les Usages, etc., des Chinois: par les Missionaires de Pékin. Paris.

Capra, Fritjof. 1975. The Tao of Physics: An Exploration of the Parallels Between Modern Physics and Eastern Mysticism. Boulder, CO: Shambhala Publications, Inc.

Chang, Stephen T., og Richard C. Miller. 1984. Kinesisk Yoga: Taoistiske Energiøvelser. Oversatt av Swami Deva Satyarthi. København: Borgen.

De Michelis, Elizabeth. 2004. A History of Modern Yoga: Patañjali and Western Esotericism. London: Continuum.

Eskildsen, Stephen. 1998. Asceticism in Early Taoist Religion. Albany, NY: SUNY Press.

Filliozat, Jean. 1969. «Taoïsme et Yoga». Journal Asiatique, 41-88. 
Habersetzer, Gabrielle, og Roland Habersetzer. 2004. Encyclopédie Technique, Historique, Biographique et Culturelle des Arts Martiaux de l'Extrême-Orient. Paris: Amphora.

Honey, David B. 2001. Incense at the Altar: Pioneering Sinologists and the Development of Classical Chinese Philology. American Oriental Series 86. New Haven, CO: American Oriental Society.

Irwin, Lee. 2014. Daoist Alchemy in the West: The Esoteric Paradigms. Udgivet online: http://esoteric.msu.edu/VolumeVI/Dao.htm\#_ednref27 (besøgt 20 november 2021).

Jung, C. G. (1961) 1989. Memories, Dreams, Reflections. New York: Vintage Books.

Kohn, Livia. 2007. «Daoyin: Chinese Healing Exercises». Asian Medicine 3 (1): 103-129. https://doi.org/10.1163/157342107x207236.

Lamont, Peter. 2005. The Rise of the Indian Rope Trick: How a Spectacular Hoax Became History. UK: Time Warner Books.

Loewe, Michael. 1979. Ways to Paradise: The Chinese Quest for Immortality. London: George Allen \& Unwin.

Lu K'uan Yü (Charles Luk). (1970) 1973. Taoist Yoga: Alchemy \& Immortality. Maine: Samuel Weiser, Inc.

Mead, G. R. S. 1906. Thrice-Greatest Hermes - Volume 2. The Theosophical Publishing Society.

Moreman, Christopher M. 2010. Beyond the Threshold: Afterlife Beliefs and Experiences in World Religions. Laham, MD: Rowman \& Littlefield Publishers.

Muller, A. Charles. 2018. «AAR Daoist Studies Sessions at AAR 2018 (including a fair amount of Buddhism)». Hnet. Tilgængelig online: https://networks.h-net.org/node/6060/discussions/3144467/aar-daoist-studiessessions-aar-2018-including-fair-amount (Besøgt 21 november 2021).

Needham, Joseph. 1983. Science and Civilisation in China Volume 5, Chemistry and Chemical Technology, Part 5, Spagyrical Discovery and Invention: Physiological Alchemy. Cambridge: Cambridge University Press.

Samuel, Geoffrey. 2013. «The subtle body in India and beyond». I Religion and the Subtle Body in Asia and the West: Between Mind and Body, redigert av Geoffrey Samuel og Jay Johnston, 33-47. London \& New York: Routledge. https://doi.org/10.4324/9780203558249. 
Seidel, Anna. 1990. Taoismus: Die Inoffizielle Hochreligion Chinas. Tokyo: Deutsche Gesellschaft für Natur- und Völkerkunde Ostasiens OAG.

Senzaki, Nyogen. 1919. 101 Zen Stories. London: Rider / Company.

Singleton, Mark. 2010. Yoga Body: The Origins of Modern Posture Practice. Oxford: Oxford University Press. https://doi.org/10.5860/choice.47-6289.

Sivin, N. 1978. «On the Word 'Taoist' as a Source of Perplexity. With Special Reference to the Relations of Science and Religion in Traditional China». History of Religions 17 (3-4): 303-330. https://doi.org/10.1086/462796.

Soo, Chee. 1977. The Chinese Art of K'ai Men. London: Gordon \& Cremonesi.

Soo, Chee. 1986. The Taoist Ways of Healing: The Chinese Art of Pa Chin Hsien. London: Aquarian Press.

Strauss, Sarah. 2005. Positioning Yoga: Balancing Acts Across Cultures. Oxford: Berg. https://doi.org/10.4324/9781003086420.

Thykier Makeeff, Tao. 2020. «Historisk Kampkunst i Nutidens Grækenland: Religion, Reception og Feltarbejdets Etiske Udfordringer». Chaos: Skandinavisk Tidsskrift for Religionshistoriske Studier 71 (1): 199-223.

Umekawa, Sumiyo. 2004. Sex and Immortality: A Study of Chinese Sexual Activities for Better-Being (Thesis submitted for the degree of Doctor of Philosophy of the University of London February 2004). Department of History School of Oriental / African Studies.

Waley, Arthur. (1934) 1977. The Way and Its Power: A Study of the Tao Tê Ching and Its Place in Chinese Thought. London: Unwin.

Wile, Douglas. 1992. Art of the Bedchamber: The Chinese Sexual Yoga Classics Including Women's Solo Meditation Texts. Albany, NY: SUNY Press.

Wile, Douglas. 2018. «Debaters of the Bedchamber: China Reexamines Ancient Sexual Practices». JOMEC Journal 12:5-69. http://doi.org/10.18573/jomec.169.

Wilhelm, Richard, og C. G. Jung. 1947. The Secret of the Golden Flower: A Chinese Book of Life Translated and Explained by Richard Wilhelm With a European Commentary by C. G. Jung. Oversatt av Cary F. Baynes. London: Kegan Paul, Trench, Trubner \& co., Ltd.

Wilhelm, Richard, og C. G. Jung. (1929) 1986. Das Geheimnis der Goldenen Blüte. Köln: Eugen Diederichs Verlag. 
Zysk, Kenneth G. 1993. «The Science of Respiration and the Doctrine of the Bodily Winds in Ancient India». Journal of the American Oriental Society 113 (2): 198-213. https://doi.org/10.2307/603025. 